\title{
Analysis Physical Characteristics of Land for Estimated Runoff Coefficient as Flood Control Effort in Comal Watershed, Central Java
}

\author{
Arina Miardini ${ }^{1}$ and Pranatasari Dyah Susanti \\ Institute of Technology Forestry Watershed Management Research Surakarta (Balai Penelitian Teknologi \\ Kehutanan Pengelolaan DAS Surakarta) \\ Jl. A. Yani-Pabelan, Kartasuro PO BOX 295 Surakarta 57102 \\ Telp. (0271) 716709, Fax (0271) 716959 \\ ${ }^{1}$ Corresponding author (email: arinamiardini@gmail.com)
}

\begin{abstract}
The vast area of critical land was evidenced to be a serious threat for watershed carrying capacity which eventually affected the hydrology imbalance in the watershed area. The purpose of this study is to identify the physical characteristics of Comal watershed which have significant influence in determining the runoff and calculating the runoff coefficient by taking into account the parameters of watershed's physical characteristics. The method used in this analysis is Cook method, unit of analysis in this study is land mapping unit. Peak discharge determination is performed by using the Rational method. The analysis showed that runoff coefficient of Comal watershed is $61.63 \%$, which can be categorized as high. The runoff coefficients and peak discharge calculations of each sub watershed, respectively, Comal Hilir of 52.65\% with peak discharge $505.68 \mathrm{~m}^{3} / \mathrm{sec}$, Genteng of $65.04 \%$ with peak discharge $542.44 \mathrm{~m}^{3} / \mathrm{sec}$, Lomeneng of $64.00 \%$ with peak discharge $194.23 \mathrm{~m}^{3} / \mathrm{sec}$, Srengseng of $64.10 \%$ with peak discharge $270.46 \mathrm{~m}^{3} / \mathrm{sec}$, and Wakung Hulu of $62.34 \%$ with peak discharge $686.64 \mathrm{~m}^{3} / \mathrm{sec}$. Comal watershed flood control priority on increasing the rate of infiltration, slope management, increasing vegetation cover and management of drainage density.
\end{abstract}

Keywords: watershed characteristic, land, runoff coefficient, flood, Comal watershed

\begin{abstract}
Abstrak
Luas lahan kritis yang makin meningkat mengancam keseimbangan hidrologi dalam DAS. Salah satu DAS yang memiliki lahan kritis dan memerlukan prioritas penanganan adalah DAS Comal. Tujuan penelitian ini adalah mengidentifikasi karakteristik fisik DAS Comal yang berpengaruh dalam penentuan koefisien aliran serta menghitung koefisien aliran dengan mempertimbangkan parameter karakteristik fisik DAS. Metode penelitian yang digunakan untuk mengetahui karakteristik fisik DAS menggunakan metode Cook. Unit analisis yang digunakan dalam penelitian ini adalah satuan lahan. Penentuan debit banjir dilakukan menggunakan metode rasional. Hasil analisis menunjukkan bahwa nilai koefisien DAS Comal yaitu 61,63\% yang termasuk kategori tinggi. Nilai koefisien aliran dan perhitungan debit pada masing masing sub DAS yaitu Comal hilir 52,65\% dengan debit sebesar 505,68 $\mathrm{m}^{3} /$ dtk, Genteng 65,04\% dengan debit sebesar 542,44 md dtk, Lomeneng 64,00\% dengan debit sebesar 194,23 $\mathrm{m}^{3} /$ dtk, Srengseng 64,10\% dengan debit sebesar 270,46 $\mathrm{m}^{3} / \mathrm{dtk}$, dan Wakung hulu 62,34\% dengan debit sebesar 686,64 $\mathrm{m}^{3} / \mathrm{dtk}$. Pengendalian banjir di DAS Comal diprioritaskan pada peningkatan laju infiltrasi, pengelolaan kemiringan lereng, peningkatan tutupan vegetasi dan pengelolaan kerapatan aliran.
\end{abstract}

Kata kunci: karakteristik DAS, DAS Comal, banjir limpasan, koefisien aliran. metode cook, rasional

\section{Introduction}

Numerous watersheds in Indonesia are enduring the impact of degradation due to exploitative land use and environmental carrying capacity. Based on Direktorat Jenderal Bina Pengelolaan Daerah Aliran Sungai and Perhutanan Sosial in Buku Statistik Kehutanan (2006 and 2011), it is mentioned that critical land area was $77.806 .880,78$ ha in 2006 and it increased by 104.202.026,20 ha in 2011. It indicates the ineffective endeavors in managing watershed due to several obstacles. The vast area of degraded land turns out to be a serious threat for watershed carrying capacity, which will eventually be a major cause for watershed hydrology imbalances. One among 
the impacts of hydrology imbalances in the watershed is flood. Sinukaban (2007) also suggests that flood is an obvious indicator of watershed dysfunction caused by the decline of infiltration as the result of eliminated vegetation cover and inappropriate land use. The ignorance of this damage will just add the long list of critical watersheds in Indonesia. Flooding will be discussed in this paper is the flood derived from land or known as the overland flow. Type flood that comes from surface runoff before entering the river system.

Rencana Pembangunan Jangka Menengah/ RPJM) 2010-2014 explicitly states a number of 108 watershed in Indonesia are included in critical condition and watershed priority (The Ministry of Forestry has issued Decree No. SK.328/Menhut-II/2009). Comal watershed is one among Priority I watersheds. Comal watershed has an essential function especially for its raw water supply for numbers of daily needs such as irrigation, households, and industry for 5 districts. The categorization of Comal watershed as Priority I is mainly caused by its flood intensity. For instance, based on the data from Badan Nasional Penanggulangan Bencana/BNPB, flood took place in Bodeh, Comal, Ulujami, Ampel, Gading, Taman, Petarukan, and Pemalang on 4 March 2014. The condition is worsened by the increasing population density and intensive natural resources exploitation, resulting in the massive watershed conditions such as landslides, erosion, sedimentation, flood, drought (Suharyono et al., 2015).

Watershed's response to the waters system is strongly affected by the physical characteristics of watershed. The characteristics can be defined as specific illustration of watershed adduced by the parameters related to morphometry, topography, soils, geology, vegetation, land use system, hydrology, and human activity (Seyhan, 1977). According to Supangat (2012), the watershed's condition relied upon the nature as well as on land use system as human involvement. In flood control efforts, an inquiry on land physical characteristics which affect the amount of runoff is required so as to formulate recommendations for flood control in a given watershed in the context of upstream to downstream watershed management efforts. The magnitude of the flood is strongly influenced by the intensity of the rainfall, watershed area and runoff coefficient. Static factors such as rainfall and watershed area is a natural factor, whereas a more dynamic runoff coefficient so that the flood control can be done by managing the runoff coefficient.

The aim of the study is to identify the physical characteristics of Comal watershed which influence the runoff determination and to calculate the runoff coefficient by examining the parameters of watershed physical characteristics. The yield of the inquiry will be the basis of flood control recommendation in Comal watershed, particularly in sub watersheds with flood vulnerability as the efforts to uphold upstream to downstream watershed management.

\section{Method}

Study was carried out in Comal watershed (DSA) in September to November 2015. Total area of Comal watershed is 82140.30 ha with $212.99 \mathrm{~km}$ in perimeter. The main river of Comal watershed is Kali Comal of 104.14 $\mathrm{km}$ in length. Materials used in this study consist of: Map of Comal watershed, data of daily precipation data of 10-year series (20052014) from 12 rain stations (Randudongkal, Sipedang, Sumubkidul, Banjardawa, Warungpring, Bongas, Moga, Brondong, Ponolawen, Kaliwadas, Sokowati, and Klayeran), digital data of Landsat 8 Imagery of 2014 Path/row 120/66 spatial resolution of 30 x 30 m, RBI Digital Map scale 1:25000, Soil Type Map scale 1:250000, and Forest area map. The tools used in this study include Notebook ASUS Core i3 with capacity of 6 GB in RAM and harddisk 500 GB, Software Arc GIS 10.1, Software Ms.Word, and Ms. Excel. 
The physical characteristics of watershed was analyzed by using Cook's method in accordance to Chow (1964) and Meijerink (1970). In this method, the estimation of runoff was carried out through runoff coefficient by examining the wathershed's characteristics of slope, inflitration, vegetation cover, and drainage density. The analysis unit in the study was land mapping unit. Meijerink (1970) in Gunawan (1991) affirms that land mapping unit is a preferred interpretation unit and landscape visual mapping unit in association with hydrology process. The step of the study is illustrated in Figure 1.

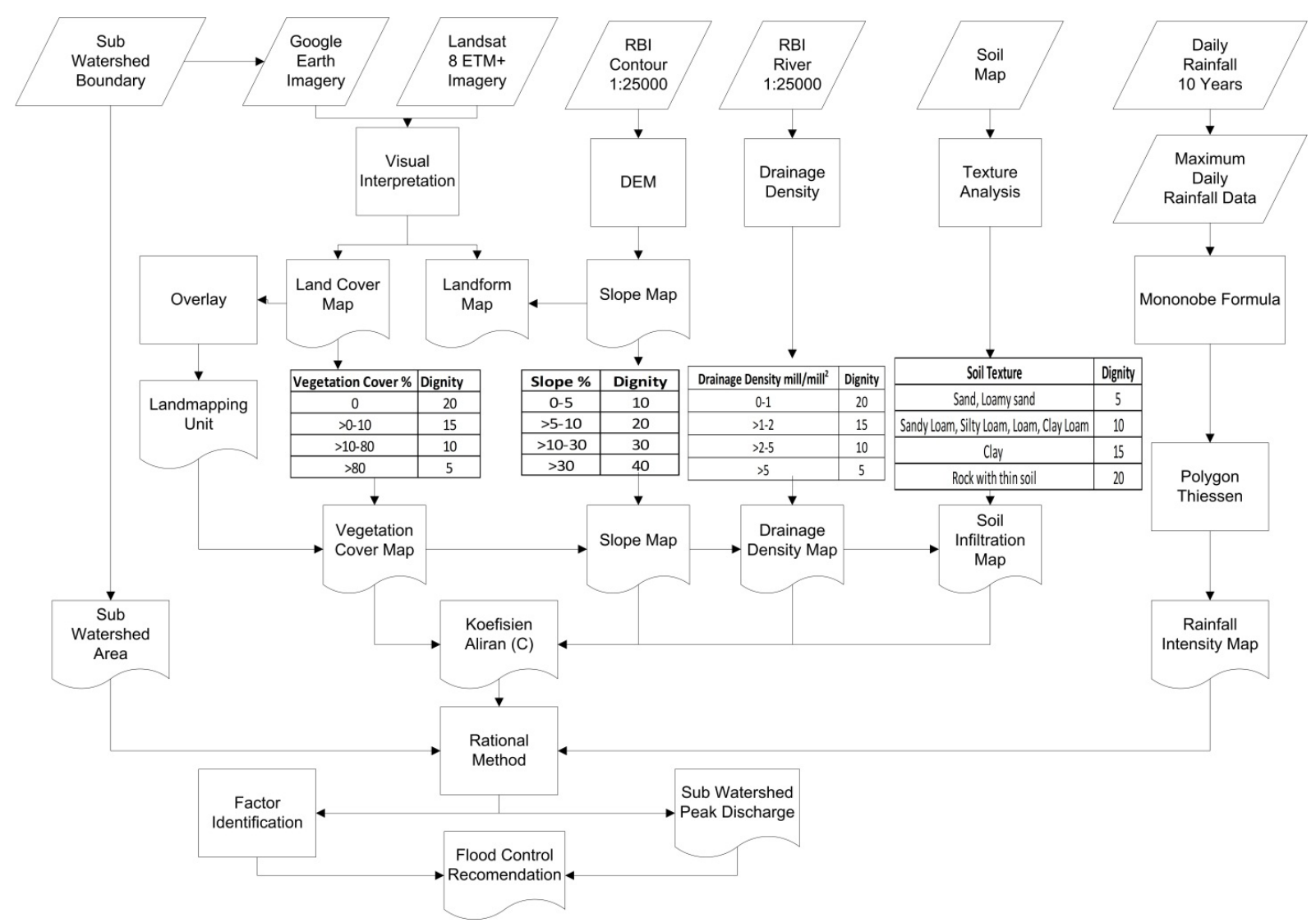

Figure 1. Research Flowchart

The value of runoff coefficient, subsequently, was classified based on Cook's method which was divided into 4 (four) classes with detail categorization as follows:

Table 2 Runoff Coefficient Classification

\begin{tabular}{ccc}
\hline Class & Criteria & Value (\%) \\
\hline I & Low & $<25$ \\
II & Normal & $>25-<50$ \\
III & High & $>50-<75$ \\
IV & Extreme & $>75-100$ \\
\hline Source: Meijerink (1970)
\end{tabular}

\section{Results and Discussion}

\section{The Physical Characteristics of Study Area}

The analysis indicates there is a total of 247 land mapping units in Comal which consists of 2353 poligons. The amount of runoff in each land mapping unit is calculated by considering the characteristics factors of watershed in Cook's method, which slope, drainage density, vegetation cover, and infiltration. These 
parameters, furthermore, are classified and proportionally scored based on their influence on runoff coefficient (Gunawan, 1991). The result of analysis is presented in Table 2.

Slope is included in the factor affecting the amount of rainfall will eventually surge as runoff. Goro (2008) and Suhardiman (2012) that the slope will affect the runoff and the water possibility to seep into the ground will be smaller so that it will increase the potential for flooding in a watershed.

The percentage of slope in each sub watershed can be figured out in Table 2. In this table, Genteng and Srengseng sub watershed have the highest percentage of slope in class $>30 \%$, respectively, of $43.76 \%$ and $52.24 \%$. Lomeneng and Wakung hulu sub watershed are evidenced to have the highest percentage in class $10-30 \%$, respectively, of $54.7 \%$ and $49.59 \%$, meanwhile Comal Hilir sub watershed has the highest percentage of $70.89 \%$ in slope of $0-5 \%$. The dominant slope in Comal watershed turns out to be susceptible, since the potential of land degradation will result on higher amount of runoff coefficient. In addition, land with hilly to steep conditions causing rainfall pours down in relatively high speed, hence, it have inadequate time to infiltrate. It is similar to Suhardiman (2012) who suggests slope is an elevation of land surface that will affect the rate of infiltration.

As illustrated in Table 2, it can be observed that the dominant vegetation cover in the class of $>80 \%$, which are Genteng sub watershed (36.6\%), Lomeneng sub watershed $(46.65 \%)$, Srengseng sub watershed $(43.28 \%)$, and Wakung Hulu sub watershed (39.3\%), while Comal Hilir sub watershed is on class of $10-80 \%$ with the percentage of $45.82 \%$. The information of vegetation cover is very significant due to its highly correlation with the runoff. The higher is the amount of vegetation in a given land, the lower will the runoff (Saribun, 2007). It is similar with the study conducted by Rajarjo (2013), in which water unretained by the vegetation and cannot seep into the ground will be a runoff that will gather in the tributaries so that the peak discharge will increase.

Drainage density is an important characteristic of watershed as it is used to evaluate the potential of runoff. It is the comparison between total area of watershed and total length of all the streams and rivers in a watershed (Raharjo, 2009). A watershed with one watercourse and numbers of tributaries' branch has a higher drainage density compared to a watershed with a watercourse and a few of tributaries (Indarto, 2010). The highest drainage density of $\left(>5 \mathrm{mill} / \mathrm{mill}^{2}\right)$ in Comal watershed (Table 6) occurred in 4 (four) sub watersheds, while Comal Hilir sub watershed has the highest drainage density in the class of $0-1 \mathrm{mil} / \mathrm{mill}^{2}$. High drainage density allows runoff from the area above the tributaries to be efficiently drained, since the rainfall will flow into the tributaries quickly, rainfall will be divided and will reduce the peak discharge.

Infiltration is important process of runoff. It determines the amount of rainfall which can be absorbed into the soil. The higher is the value of infiltration, the smaller is the difference between rainfall intensity and infiltration capacity, since the runoff is smaller and so is the peak discharge. According to Widianto et al., (2004), in the case of rainfall is directly poured down to the ground, the soil aggregates will be destroyed and it causes the space of macro pore is reduced so that the infiltration rate is declined. In addition to the vegetation as the resistor of the amount of rainfall into the ground, soil infiltration is also affected by the nature of soil physical properties. It is stated by Rohmat and Sukarno (2006) that the infiltration rate is a function of permeability parameters and soil moisture which is closely related to the soil physical properties.Based on the result of the analysis (Table 5), on infiltration parameter, there are three sub watersheds are included in the slow class, namely, Genteng of $68.98 \%$, Lomeneng of $77.68 \%$, and Srengseng of $94.33 \%$, Comal Hilir of $61.97 \%$, and Wakung Hulu of $49.28 \%$ 
are included in the category of medium. It indicates that soil texture is evidenced to have influence on infiltration rate. According to Arsyad (2000), soil properties which determine and limit infiltration capacity is soil structure and it is powerfully affected by water texture and content. In addition, Fonth and
Adisoemarto (1994) in their study imply that the relative size of soil particle is expressed in terms of texture refers to the smoothness or roughness of the soil. Soils with smooth texture, such as clay, have small pore spaces, hence, the infiltration is slow as it requires long time for rainfall to fill the soil pores.

Table 2 Parameter of Runoff Coefficient Estimation Values in Each Sub watershed

\begin{tabular}{|c|c|c|c|c|c|c|c|c|c|c|c|c|c|}
\hline \multirow{3}{*}{ No } & \multirow{3}{*}{$\begin{array}{c}\text { Sub } \\
\text { watershed }\end{array}$} & \multicolumn{12}{|c|}{ Parameter of Runoff Coefficient Estimation } \\
\hline & & \multicolumn{3}{|c|}{ Slope } & \multicolumn{3}{|c|}{ Vegetation Cover } & \multicolumn{3}{|c|}{ Drainage Density (mill/mill2) } & \multicolumn{3}{|c|}{ Infiltration Rate } \\
\hline & & Class & $\begin{array}{c}\text { Area } \\
\text { (ha) }\end{array}$ & $\begin{array}{c}\text { Percentage } \\
(\%)\end{array}$ & Class & $\begin{array}{c}\text { Area } \\
\text { (ha) }\end{array}$ & $\begin{array}{c}\text { Percentage } \\
(\%)\end{array}$ & Class & $\begin{array}{c}\text { Area } \\
\text { (ha) }\end{array}$ & $\begin{array}{c}\text { Percentage } \\
(\%)\end{array}$ & Class & $\begin{array}{c}\text { Area } \\
\text { (ha) }\end{array}$ & $\begin{array}{c}\text { Percentage } \\
(\%)\end{array}$ \\
\hline \multirow{4}{*}{1} & \multirow{4}{*}{$\begin{array}{l}\text { Comal } \\
\text { Hilir }\end{array}$} & $>30 \%$ & 208.41 & 0.96 & $>80 \%$ & 940.01 & 4.33 & $>5$ & 8258.23 & 38.04 & Moderate & 13453.28 & 61.97 \\
\hline & & $0-5 \%$ & 15389.5 & 70.89 & $10-80 \%$ & 9947.22 & 45.82 & $>2-5$ & 1478.41 & 6.81 & Slow & 8227.84 & 37.90 \\
\hline & & $10-30 \%$ & 5119.06 & 23.58 & $0-10 \%$ & 6072.10 & 27.97 & $>1-2$ & 1120.2 & 5.16 & Ignored & 28.22 & 0.13 \\
\hline & & $5-10 \%$ & 992.12 & 4.57 & $0 \%$ & 4750.00 & 21.88 & $0-1$ & 10852.5 & 49.99 & & & \\
\hline \multirow{4}{*}{2} & \multirow{4}{*}{ Genteng } & $>30 \%$ & 8249.30 & 43.76 & $>80 \%$ & 6899.55 & 36.6 & $>5$ & 8358.64 & 44.34 & Moderate & 3928.60 & 20.84 \\
\hline & & $0-5 \%$ & 2803.18 & 14.87 & $10-80 \%$ & 3210.37 & 17.03 & $>2-5$ & 1557.11 & 8.26 & Slow & 13003.59 & 68.98 \\
\hline & & $10-30 \%$ & 7563.12 & 40.12 & $0-10 \%$ & 4397.99 & 23.33 & $>1-2$ & 1374.26 & 7.29 & Igored & 1919.06 & 10.18 \\
\hline & & $5-10 \%$ & 235.64 & 1.25 & $0 \%$ & 4343.33 & 23.04 & $0-1$ & 7561.23 & 40.11 & & & \\
\hline \multirow{4}{*}{3} & \multirow{4}{*}{ Lomeneng } & $>30 \%$ & 2336.45 & 34.06 & $>80 \%$ & 3200.10 & 46.65 & $>5$ & 3294.77 & 48.03 & Moderate & 508.31 & 7.41 \\
\hline & & $0-5 \%$ & 588.57 & 8.58 & $10-80 \%$ & 718.91 & 10.48 & $>2-5$ & 412.961 & 6.02 & Slow & 5328.70 & 77.68 \\
\hline & & $10-30 \%$ & 3752.32 & 54.7 & $0-10 \%$ & 1590.10 & 23.18 & $>1-2$ & 391.695 & 5.71 & Ignored & 1022.80 & 14.91 \\
\hline & & $5-10 \%$ & 182.47 & 2.66 & $0 \%$ & 1350.70 & 19.69 & $0-1$ & 2760.39 & 40.24 & & & \\
\hline \multirow{4}{*}{4} & \multirow{4}{*}{ Srengseng } & $>30 \%$ & 4982.13 & 52.24 & $>80 \%$ & 4127.61 & 43.28 & $>5$ & 6389.79 & 67 & Moderate & 0 & 0 \\
\hline & & $0-5 \%$ & 458.73 & 4.81 & $10-80 \%$ & 1174.00 & 12.31 & $>2-5$ & 453.961 & 4.76 & Slow & 8996.25 & 94.33 \\
\hline & & $10-30 \%$ & 3990.28 & 41.84 & $0-10 \%$ & 2887.80 & 30.28 & $>1-2$ & 515.952 & 5.41 & Ignored & 540.75 & 5.67 \\
\hline & & $5-10 \%$ & 105.86 & 1.11 & $0 \%$ & 1347.58 & 14.13 & $0-1$ & 2177.3 & 22.83 & & & \\
\hline \multirow{4}{*}{5} & \multirow{4}{*}{$\begin{array}{l}\text { Wakung } \\
\text { Hulu }\end{array}$} & $>30 \%$ & 6215.14 & 24.68 & $>80 \%$ & 9896.88 & 39.3 & $>5$ & 10690.1 & 42.45 & Moderate & 12410.14 & 49.28 \\
\hline & & $0-5 \%$ & 3243.56 & 12.88 & $10-80 \%$ & 1876.13 & 7.45 & $>2-5$ & 4099.78 & 16.28 & Slow & 9957.32 & 39.54 \\
\hline & & $10-30 \%$ & 12488.21 & 49.59 & $0-10 \%$ & 7552.35 & 29.99 & $>1-2$ & 506.176 & 2.01 & Ignored & 2815.45 & 11.18 \\
\hline & & $5-10 \%$ & 3236.00 & 12.85 & $0 \%$ & 5857.54 & 23.26 & $0-1$ & 9886.81 & 39.26 & & & \\
\hline
\end{tabular}

\section{Estimation of Runoff Coefficient}

The value of runoff coefficient in each sub watershed in Comal Watershed (C) ranges from 52.65 to 65.04 with an average value of 61.63 (Table 3). From the analysis, the highest coefficient value was obtained by Genteng sub watershed and the lowest was Comal Hilir sub watershed. $\mathrm{C}$ value indicates that Comal watershed can be categorized as high, it means that high amount rainfall becomes runoff and potential to overland flow. (Figure 2). 
Table 3 Runoff Coefficients of Sub watershed in Comal Watershed

\begin{tabular}{clccccc}
\hline No & Sub watershed & Score S & Score V & Score I & Score D & Score C \\
\hline 1 & Comal Hilir & 15.46 & 13.37 & 10.46 & 13.36 & 52.65 \\
2 & Genteng & 31.24 & 11.63 & 10.03 & 12.14 & 65.04 \\
3 & Lomeneng & 31.36 & 10.77 & 9.98 & 11.88 & 64.00 \\
4 & Srengseng & 34.14 & 10.76 & 10.00 & 9.20 & 64.10 \\
5 & Wakung Hulu & 28.59 & 11.85 & 9.99 & 11.90 & 62.34 \\
& Rata-rata & 28.16 & 11.68 & 10.09 & 11.70 & 61.63 \\
\hline
\end{tabular}

Source: Data Processing and Analysis, 2015

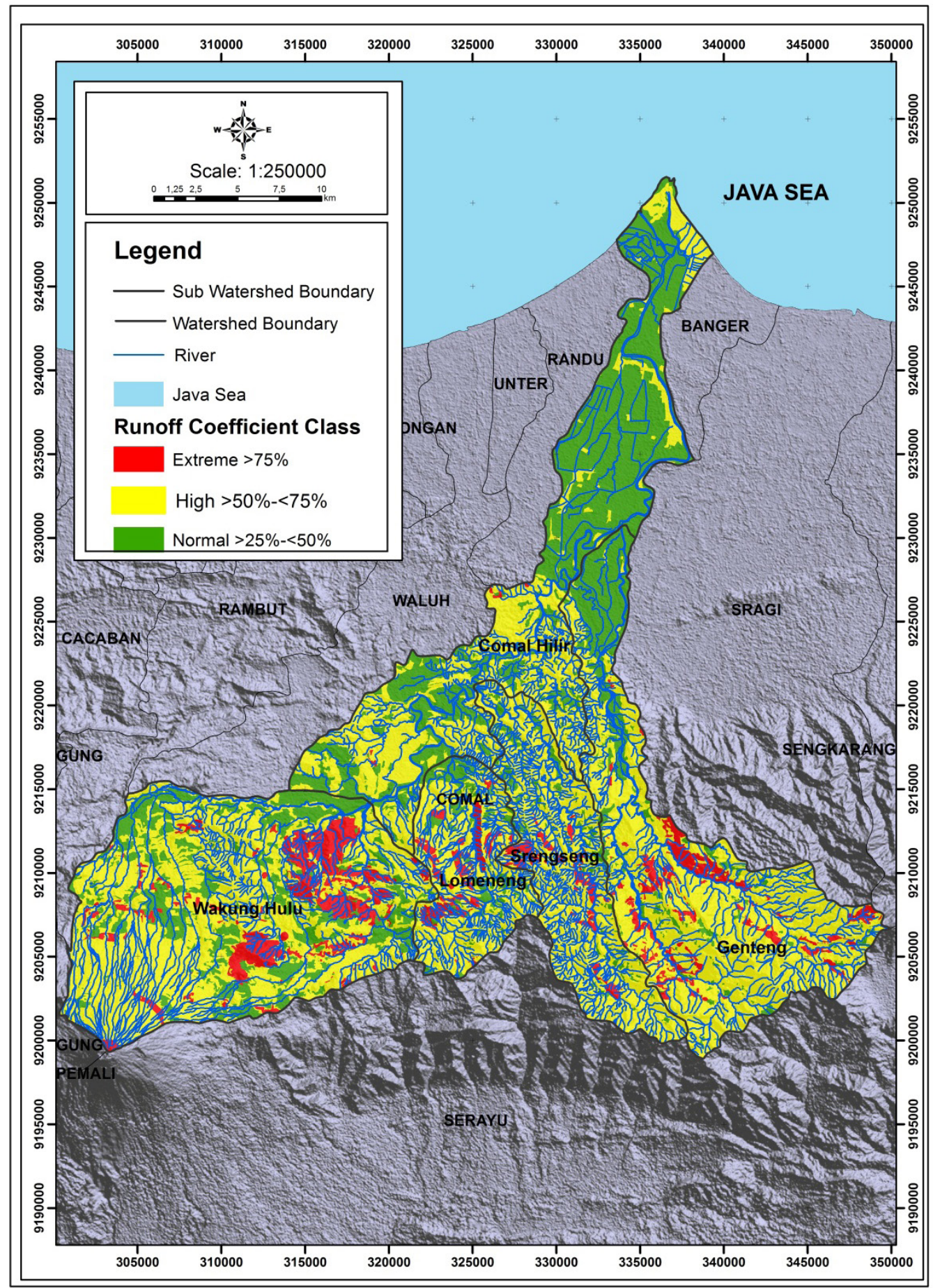

Figure 2. Map of Runoff Coefficient of Comal Watershed 
Assessment of peak discharge used in this study is done through Rational Method which is affected by the factors of runoff coefficient, rainfall intensity, and watershed's area. Runoff is the most dynamic response in a watershed that is related to rainfall (Liang et al. and Mu et al., 2015). Data of maximum rainfall intensity is determined through the daily rainfall data of rain gauge station. Assessment of the maximum daily rainfall is done by calculating the Thiessen coefficient of each rain station. The result of rainfall calculation indicates the maximum daily precipitation in Comal watershed was $124.26 \mathrm{~mm}$ which occurred on January 29.

Rainfall and runoff are interconnected, and further, they constitute a major problem in the field of hydrology (Liang et al., 2015). Monde (2010) suggests that in addition to the extensive catchment area, the amount of rainfall intensity also affects the amount and velocity of runoff. Based on the calculation, rainfall intensity of Comal watershed was $15.91 \mathrm{~mm}$ with time of concentration of 7 hours 54 minutes. The value of peak discharge in each sub watershed can be calculated as follows in Table 9.

Estimation on the peak discharge in Comal watershed which was calculated in each sub watershed adduced that the highest discharge was in Wakung Hulu sub watershed of 686.64 $\mathrm{m}^{3} / \mathrm{sec}$ and the lowest was in Srengseng sub watershed of $270.46 \mathrm{~m}^{3} / \mathrm{sec}$. The largest contributor of overland flow in Comal watershed was Wakung Hulu sub watershed. Wakung Hulu sub watershed is located in the upper area of Comal watershed. It is dominated by hilly to steep slopes, high drainage density, slow-to-moderate soil infiltration, and low density vegetation cover.

Table 9 Calculation of Peak Discharge $(Q)$ of Sub watersheds in Comal Watershed

\begin{tabular}{clcccc}
\hline No & Sub watershed & $\mathbf{C}$ & $\mathbf{I}(\mathbf{m m} / \mathbf{h r})$ & $\mathbf{A ~ ( k m 2 )}$ & $\mathbf{Q}(\mathbf{m 3} / \mathbf{s e c})$ \\
\hline 1 & Comal Hilir & 0.53 & 15.91 & 217.09 & 505.68 \\
2 & Genteng & 0.65 & 15.91 & 188.51 & 542.44 \\
3 & Lomeneng & 0.64 & 15.91 & 68.60 & 194.23 \\
4 & Srengseng & 0.64 & 15.91 & 95.37 & 270.46 \\
5 & Wakung hulu & 0.62 & 15.91 & 251.83 & 686.64 \\
\hline
\end{tabular}

Source: Data Processing and Analysis, 2015

In managing the attempts of flood because of land (overland flow) control in Comal watershed, the most significant parameter from the four analyzed parameters should be determined. In accordance to the assessment of correlation on $\mathrm{C}$ value (Table 5).

Table 5 Correlation Value of Runoff Coefficient Estimation Factors

\begin{tabular}{cccccc}
\hline No & Sub watershed & Slope & Vegetation cover & Infiltration & Drainage density \\
\hline 1 & Comal Hilir & $0.947^{* *}$ & $0.974^{* *}$ & $0.995^{* *}$ & $0.989^{* *}$ \\
2 & Genteng & $0.984^{* *}$ & $0.856^{* *}$ & $0.990^{* *}$ & $0.975^{* *}$ \\
3 & Lomeneng & $0.977^{* *}$ & $0.847^{* *}$ & $0.990^{* *}$ & $0.949^{* *}$ \\
4 & Srengseng & $0.979^{* *}$ & $0.856^{* *}$ & $0.989^{* *}$ & $0.904^{* *}$ \\
5 & Wakung hulu & $0.975^{* *}$ & $0.907^{* *}$ & $0.991^{* *}$ & $0.970^{* *}$ \\
\hline
\end{tabular}

Source: Data Processing and Analysis, 2015

Implication toward Flood Control Efforts The main target of flood control is the restoration, reclamation and conservation of land use in accordance with the function and the region or spatial plan that can be controlled runoff because the functioning of vegetation cover on any land use and functioning of water infiltration into the soil 
region. Flood management in each watershed will be different according to the contribution of each parameter in the assessment of runoff coefficient. Based on the correlation analysis, the priority control for Comal watershed are: (1) increasing the rate of infiltration, (2) slope management, (3) increasing vegetation cover and (4) management of drainage density, with the following explanations:

a. Increasing the rate of infiltration Increasing infiltration capacity can be increased through the making biopori especially in residential areas and adding soil improvement materials. According to Subagyo (2004), the runoff, soil, and infiltration capacity controls are vital in the runoff management. Biopori is a small hole in the ground which is naturally formed by the activity of soil organisms. The existence of the organic material can be as a unifying or binding soil grains (granulator), a source of nutrients, enhancing the ability of soil holds water (holding capacity), an addition to the cation exchange capacity (cation exchange capacity) as well as the energy source for microbes and makroba soil (Gardiner and Miller 2004). Soil organic matter is a source of food for soil organisms, thus stimulating the formation of soil structure over crumbs and ultimately can improve soil infiltration capacity.

Biologically, to promote the improvement of soil infiltration capacity, the are required. Simple and inexpensive method is the treatment of compost or organic fertilizer. The addition of organic matter in the soil is capable in slowing down the rate of runoff, increasing the infiltration, and stabilizing soil aggregate (Nuraeni et al., 2013). In addition to organic matter, utilization of soil fauna such as earthworms, can improve soil infiltration. According to Subowo (2011), endogeic earthworm can construct soil pores and unite the soil layers. To support the earthworm's breeding and populations, organic fertilizer is required. Organic matter as feed either vertically or to the inner layer of soil, can stimulate the worm to crawl up to the inner layer, so as to strengthen the absorption of water and to improve the soil pores (Subowo, 2011). It is similar to the analysis delivered by Iqbal (2015) that the addition of compost can increase the activity and population of soil organisms, improve soil structure, increase the ability to bind water and soil aggregates, and increase infiltration.

b. Slope management

Land management in areas with steep slopes to steep and increasing vegetation cover by applying the principles of conservation of soil and water. A combination of conservation techniques encompassing of vegetative, mechanics, and chemistry is ideal for flood control. Mechanically, the factor of long and steep slopes can be overcome by cutting through the construction of terraces and contour planting. According to Arsyad (2010), bench terracing is able to reduce the slope length, as well as to decrease the runoff velocity and quantity. Mechanical technique is accountable for the management of slope and river. River rehabilitation is also significant in flood control effort. Setyowati (2012) suggests the establishment of well built embankment, particularly on the bank of the river, which is expected to withstand the high discharge, the establishment of constructed channels flowing into the main river is an attempt to reduce the pool due to the poor infiltration, in addition to crops planting with solid roots on the riparian areas which can strengthen the natural levee.

c. Increasing vegetation cover

The increasing vegetation cover can through several techniques such as agroforestry and the utilization of grasses. Agroforestry systems and grasses can be applied as a flood control. According to Atmojo (2008), agroforestry has an important role in watershed management and flood control as it is accountable in 
covering the ground completely so as to reduce the runoff and to improve the soil infiltration capacity. In addition, agroforestry systems with a variety of crops will construct solid roots, it will maintain the slope stability. Soan et al., (2011) affirms the crops and their residue can be used as protective ground against raindrops and runoff carrying capacity and subsequently, it will improve soil infiltration capacity. In addition to agroforestry, grasses can be used as terrace reinforcement. Nuraeni et al. (2013) confirms that mechanical technique must be balanced with vegetative conservation by planting terrace crops such as grasses which serves as compost, fodder, and soil binder to prevent landslides. The combination between grass and agroforestry system can covered the ground surface, so it can reduce the runoff.

d. Management of drainage density According to Pallard et al. (2009), drainage density is a catchment morphology and may influence significantly the frequency regime of flood flows and control the formation of river flows. Because of that, the management of drainage density is very important to reduce runoff.

Some management drainage density can be through 1) the normalization stream with the manufacture of plaster riverbanks (beronjong) in order to prevent erosion, landslides and increase the capacity of water, 2) dredging river sediment, 3) creation of water storage as a water transit

, 4) Preparation diversion if necessary for the flow solver, 5) Protection of river banks and reservoirs, 5) construction Rehabilitation riverbanks and levee.

\section{Conclusion}

Several physical characteristics of Comal watershed were analyzed, consisting of slope, infiltration, vegetation, and drainage density. As previously elaborated, conclusion can be drawn that from 5 (five) sub watersheds in Comal watershed, 2 sub watersheds are in slope of $>30 \%, 2 \mathrm{sub}$ watersheds are in slope of $0-30 \%$, and 2 sub watershed is in slope of $0-5 \%$. The dominant vegetation cover in Comal watershed is $>80 \%$, dominant drainage density is categorized in class $>5 \mathrm{mill} / \mathrm{mill}^{2}$, and dominant infiltration rate can be considered as slow. Runoff coefficient of Comal watershed is $61.63 \%$ or high category. The values of runoff coefficient and discharge calculation of each sub watershed are, respectively, Comal Hilir of $52.65 \%$ with peak discharge $505.68 \mathrm{~m}^{3} /$ sec, Genteng of $65.04 \%$ with peak discharge $542.44 \mathrm{~m}^{3} / \mathrm{sec}$, Lomeneng of $64.00 \%$ with peak discharge $194.23 \mathrm{~m}^{3} / \mathrm{sec}$, Srengseng of $64.10 \%$ with peak discharge $270.46 \mathrm{~m}^{3} /$ sec, and Wakung Hulu of $62.34 \%$ with peak discharge $686.64 \mathrm{~m}^{3} / \mathrm{sec}$. Comal watershed flood control priority on increasing the rate of infiltration, slope management, increasing vegetation cover and management of drainage density.

\section{References}

Atmojo. S. W. 2008. Peran Agroforestri Dalam Menanggulangi Banjir Dan Longsor DAS. National Seminar "Pendidikan Agroforestry Sebagai Strategi Menghadapi Pemanasan Global” organized by Faculty of Forestry, UNS. Solo, 4 March 2008.

Arsyad, S. 2000. Konservasi Tanah dan Air. IPB Press. Bogor

BNPB. 2015. Data Kejadian Banjir. http:/geospasial.bnpb.go.id/pantauan bencana /data/ databanjir.php. Acessed at 8 October 2015.

Departemen Kehutanan. 2006. Buku Statistik Kehutanan Indonesia Tahun 2006. http://www. dephut.go.id/index.php?q=id/node/6122. Acessed at 2 March 2014 
Departemen Kehutanan. 2011. Buku Statistik Kehutanan Indonesia Tahun 2011. http://www. dephut.go.id/INFORMASI/STATISTIK/2001/Statistik2001.htm. Accessed at 2 March 2014.

Dewi. I. G. A. S. U., Trigunasih. N. M., and Kusmawati. T. 2012. Prediksi Erosi Dan Perencanaan Konservasi Tanah Dan Air Pada Daerah Aliran Sungai Saba. E-Journal Agroeoteknologi Tropika. Vol. 1, No. 1, July 2012: 12-23.

Gardiner, DT dan Miller RW. 2004. Soil in Our Environment 10th Edition. Prentice Hall. New Jersey

Goro, G.L. 2008. Kajian Pengaruh Intensitas Hujan Pada Jenis Tanah Regosol Kelabu Untuk Kemiringan Lereng Yang Berbeda. Jurnal Wahana Teknik Sipil Vol. 13 No. 2 August 2008: 86-98

Gunawan, T. 1991. Penerapan Tekhnik Penginderaan Jauh untuk Menduga Debit Puncak menggunakan Karakteristik Lingkungan Fisik DAS. Studi Kasus di Daerah aliran Sungai Bengawan Solo Hulu. Disertation. Magister Program. Institut Pertanian Bogor. Bogor

Hadisusanto, N. 2010. Aplikasi Hidrologi. Jogja Mediautama. Yogyakarta

Indarto. 2010. Hidrologi, Dasar Teori dan Contoh Aplikasi Model Hidrologi. Bumi Aksara. Jakarta

Iqbal. 2015. Pengaruh Bahan Organik Terhadap Pemadatan Tanah Dan Produksi Tanaman Tebu Pada Lahan Kering. Jurnal AgriTechno (Vol. 8, No. 1, April 2015): 10-19.

Liang. D., Ozgen. I.O., Hinkelmaun. R., Xiao. Y. and Chen. J. M. 2015. Shallow water simulation of overland flows in idealized catchments. Environ Earth Sci (2015) 74:7307-7318.

Meijerink, A.M.J. 1970 Photo Interpretation in Hydrology A Geomorphological Approach. ITC. Delf

Monde. A. 2010. Pengendalian Aliran Permukaan dan Erosi Pada Lahan Kakao di DAS Gumbasa, Sulawesi Tengah. Media Litbang Sulteng III (2): September 2010: 131-136.

Mu. W., Yu. F., Li. C., Tian. J. Liu. J. and Zhao. N. 2015. Effects of Rainfall Intensity and Slope Gradient on Runoff and Soil Moisture Content on Different Growing Stages of Spring Maize. Water Journal, 7: 2990-3008.

Nuraeni, Sugiyanto, and Zaenal. 2013. Usahatani Konservasi di Hulu DAS Jeneberang (Studi Kasus Petani Sayuran di Hulu DAS Jeneberang Sulawesi Selatan). Jurnal Manusia dan Lingkungan. Vol 20 (2) July 2013: 173-183.

Pallard. B., Castellarin. S. and Montanari. A. A Look at The Links Between Drainage Density And Flood Statistics. Hydrology and Earth System Sciences, 13: 1019-1029.

Rajarjo. P. D. 209. Perubahan Penggunaan Lahan Das Kreo Terhadap Debit Puncak Dengan Aplikasi Penginderaan Jauh. Jurnal Riset Geologi dan Pertambangan Vol. 19 No. 2 (2009). 69 - 84.

Republik Indonesia. 2009. Keputusan Menteri Kehutanan No. SK. 328/Menhut- II/2009 tentang Penetapan Daerah Aliran Sungai (DAS) Prioritas dalam Rangka Rencana Pembangunan Jangka Menengah (RPJM) tahun 2010-2014. Ministry of Forestry. Jakarta

Rohmat. D. and Soekarno. I. 2006. Formulasi Efek Sifat Fisik Tanah terhadap Permeabilitas dan Suction Head Tanah (Kajian Empirik untuk Meningkatkan Laju Infiltras .Jurnal Bionatura, Vol. 8 No. 1 March 20: 1-9. 
Setyowati. D. L. 2014. Upaya Konservasi Lingkungan Pada Kawasan Industri Candi Kota Semarang Indonesian. Journal of Conservation. Vol. 3 No. 1 - Juni 2014 : 58-66.

Seyhan, E. 1977. Fundamentals of Hydrology. Translated by S, Subagyo. 1993. Dasar-Dasar Hidrologi. Second edition. Gajah Mada University Press. Yogyakarta

Sinukaban, N. 2007. Peranan Konservasi Tanah dan Air dalam Pengelolaan Daerah Aliran Sungai. Bunga Rampai Konservasi Tanah dan Air 2004-2007. Masyarakat Konservasi Tanah dan Air. Jakarta

Soan. Pentewati. P., and Susilawati. 2011. Mengatasi Kerusakan Daerah Tangkapan Air Pada Pulau-Pulau Kecil Dengan Upaya Konservasi Tanah Dan Air Yang Didukung Oleh Ketersediaan Air Melalui Sistem Jebakan Air Berantai Pada Alur-Alur Alam. Jurnal Sipil UNWIRA Vol. 2 No. 1 September 2011: 16-23.

Subagyono, K., U. Haryati, and S.H. Talao'ohu. 2004. Teknologi konservasi air pada pertanian lahan kering. p. 151-188. In Konservasi Tanah pada Lahan Kering Berlereng. Center of Soil and Agroclimate Research and Development. Bogor.

Subowo. 2011. Penambangan Sistem Terbuka Ramah LIngkungan dan Upaya Reklamasi Pasca Tambang untuk Memperbaiki Kualitas Sumberdaya Lahan dan Hayati Tanah. Jurnal Sumberdaya Lahan. Vol 5, No. 2 December 2011.

Suhardiman. Pengaruh Intensitas Hujan dan Kemiringan Lereng Terhadap Laju Kehilangan Tanah Pada Tanah Regosol Kelabu. Faculty of Agriculture. Universitas Hasanuddin. Makassar. 64 p.

Suharyono. E., Supriyadi, and Brian. 2015. Penilaian Daerah Tangkapan Air DAS Comal Dlam Upaya Peningkatan Kualitas Lingkungan di Kabupaten Pemalang. Agromedia. Vol. 33 No. 2 September 2015: 87-93.

Sunarti, Sinukaban. N., Sanim. B., and Tarigan. S. D. 2008. Konversi Hutan Menjadi Lahan Usahatani Karet dan Kelapa Sawit serta Pengaruhnya Terhadap Aliran Permukaan dan Erosi Tanah di DAS Batang Pelepat. Jurnal Tanah Tropika, 13 (3), 2008: 253-260.

Supangat. A. B. 2012. Karakteristik Hidrologi Berdasarkan Parameter Morfometri Das Di Kawasan Taman Nasional Meru Betiri. Journal Vol. 9 No. 3: 275-283.

Widianto, Suprayogi. D., Noveras. H., Widodo. R. H., Purnomosidhi. P., and Noordwijk. 2004. Alih Guna Lahan Hutan Menjadi Lahan Pertanian: Apakah Fungsi Hidrologis Hutan Dapat Digantikan Sistem Kopi Monokultur. Junal Agrivita. Vol 26 no. 1: 47-52. 